\title{
Development of Communication Practices in Zagreb Public Transport System
}

Original scientific paper _ DOI 10.22522/cmr20180233 _ received on 29 October 2018 UDK: 659.4(091)_659.43-057.5:656(497.521.2)

- . . . . n

\section{Zdeslav Milas, MSc}

Edward Bernays University College, Zagreb, Croatia.

Email: zdeslav.milas@bernays.hr (corresponding author)

\section{Tomislav Jurić}

Zagreb Holding, Zagreb, Croatia.

Email: tomislav.juric@zgh.hr

\section{Abstract}

The historical development of PR in Croatia has not been systematically researched. Professional and academic literature considers 1964 as the start of the PR profession, when the first position of PR Manager was established in Hotel Esplanade in Zagreb (Tomašević, 2002; Skoko, 2004; Tomić, 2008; Jugo, 2012; Tkalac Verčič, 2016). The objective of this paper is to research communication practice in the public transport system using original sources. By analysing credible media and internal records on public transport models operating today within the framework of Zagreb Electric Tram (ZET), irrefutably confirmed is the application of PR tactics ahead of the start and exploitation of the first model of organised public transport in Zagreb - the funicular. While establishing the administrative preconditions for the construction of the funicular in 1888 and 1889, identified in the records is the use of specific techniques, tools and journalistic genres in public transport. Researched was the significant attention Zagreb Electric Tram (ZET) dedicated to informing internally, and already in April 1959, nine years prior to Podravka, which was considered the first to start with this practice, ZET began issuing a newspaper with a clearly defined and established editorial policy and structure, even developing a correspondent network and other internal communication channels. Furthermore, a professional information service established in 1962 (Jurić, 2016). Internal communication further extends to other communication channels, and noticeable is the influence of the political social context on the editorial policy, with probable censorship.

Keywords: history, public relations, public transport, internal communication 


\section{Razvoj komunikacijske prakse u sustavu zagrebačkog javnog prijevoza}

Izvorni znanstveni rad_ DOI 10.22522/cmr20180233 _ primljeno 29. listopada 2018.

UDK: 659.4(091) _ 659.43-057.5:656(497.521.2)

\section{Zdeslav Milas, MSc}

Edward Bernays University College, Zagreb, Croatia.

Email: zdeslav.milas@bernays.hr

\section{Tomislav Jurić}

Zagrebački holding, Zagreb, Croatia.

Email: tomislav.juric@zgh.hr

\section{Sažetak}

Povijesni razvoj odnosa s javnošću u Hrvatskoj sustavno nije istražen. Stručna i znanstvena literatura smatra da službeni početak profesije odnosa s javnošću datira iz 1964. kada je stvoreno prvo radno mjesto PR managera u Hotelu Esplande u Zagrebu (Tomašević, 2002; Skoko 2004; Tomić 2008; Jugo 2012; Tkalac Verčič, 2016). U ovom radu cilj je istražiti komunikacijsku praksu javnog prijevoznog sustava korištenjem izvornih vrela. Analizom vjerodostojnih medijskih i internih zapisa o modelima javnog prijevoza koji danas djeluju u okvirima organizacije Zagrebački električni tramvaj, nepobitno se potvrđuje primjena taktika odnosa s javnošću koja je nedvojbeno registrirana uoči početka izgradnje i eksploatacije prvog modela organiziranog javnog prijevoza u Zagrebu - uspinjače. Tijekom stvaranja administrativnih preduvjeta za izgradnju uspinjače 1888. i 1889. godine iz zapisa se prepoznaju prva korištenja pojedinih tehnika, alata i novinarskih žanrova u djelatnosti javnog prijevoza. Istraženo je kako je značajnu pažnju Zagrebački električni tramvaj pridao internom informiranju te u travnju 1959. godine, devet godina prije Podravke, za koju se smatralo da je s praksom započela prva, ZET započinje izdavati novine s jasno definiranom i poznatom uređivačkom politikom i strukturom, razvijajući čak i dopisničku mrežu, a 1962. osniva se profesionalna informativna služba (Jurić, 2016). Interna se komunikacija proširuje i drugim internim komunikacijskim kanalima, a primjetan je utjecaj političkog društvenog konteksta na uređivačku politiku, uz vrlo vjerojatnu cenzuru.

Ključne riječi: povijest, odnosi s javnošću, interna komunikacija, javni prijevoz 


\section{Uvod}

Nastojeći detektirati začetke odnosa s javnošću znanstvenici odlaze u daleku prošlost, promatrajući područje interesa čak i kroz biblijsku prizmu (Merten, 1997 prema Lennardt, 2008, str. 10; Grunig, Hunt, 1984, str. 15-16). Elementi odnosa s javnošću mogu se naći i u drevnoj Indiji, gdje su pojedinci u javnosti širili pozitivne glasine o javnoj vlasti, a u političkom rječniku starih Rimljana postoje izrazi koji podsjećaju na moderne koncepte odnosa s javnošću, kao što je izraz vox populi, odnosno glas javnosti (Cutlip, Center, Broom, 2003, str. 102). Američki pionir odnosa s javnošću Edward Luis Bernays (1952, str. 13) u svojoj knjizi Public Relations, tražeći povijesne izvore odnosa s javnošću, pokušava iste objasniti na primjerima antičkih priča viteških djela babilonskih i staroperzijskih kraljeva. Slično tumači i njemački pionir odnosa s javnošću Albert Oeckl (1976, str. 93-94), smatrajući da su Aleksander Veliki, Gaj Julije Cezar, Machiavelli i Martin Luther imali svojevrsne svjesno oblikovane odnose s javnošću. Franz Ronneberger i Manfred Rühl (1992, str. 42) takva tumačenja iz doba prije industrijalizacije mogu uvjetno prihvatiti ukoliko se poimanje odnosa s javnošću načelno persuazivno definira.

Početci američkih odnosa s javnošću ponajprije se smještaju u vrijeme Američke revolucije (1765. - 1783.), a ustrojavanje prvog odjela korporativnih odnosa s javnošću u kompaniji

Westinghouse 1889. sa svrhom promocije sustava izmjenične struje, što je predstavljalo revolucionarni napredak u energetici, dok se u prometnom sektoru pojavljuju u američkoj željeznici te se vežu uz Godišnjak željezničke literature iz 1897. godine (Cutlip, Center, Broom, 2003, str. 102).

James Grunig i Todd Hunt (1984) komunikacijske odnose s raznim javnostima stavljaju u povijesni kontekst definirajući četiri modela kroz razvoj američke profesije. Pri tome prvi začeci se detektiraju krajem 19. stoljeća kroz propagandni model tiskovne agenture, zatim javnog informiranja koji je vezan uz pionira Ivy Leedbetter Leeja te naposljetku dva dvosmjerna modela, i to persuazivnog, asimetričnog i simetričnog, čija je svrha postići međusobno razumijevanje (Fawkes, 2008, str. 29-31). S razdobljem globalne informatizacije i razvoja tehnologije, javljaju se i suvremeni odnosi s javnošću (Tomić, 2008, str. 35), a sredinom šezdesetih godina prošlog stoljeća započinje brže i kvalitetnije međusobno komuniciranje. 
Za razliku od američke ili njemačke, hrvatska povijest odnosa s javnošću vrlo je slabo istraživana i prije svega nije povezana u odgovarajući društveno-politički i gospodarski povijesni kontinuitet. Božo Skoko (2004, str. 6) začetke organiziranih odnosa s javnošću u Hrvatskoj opisuje s razvojem turizma, posebno u hotelijerstvu. Emilija Tomašević (2002, str. 9) navodi da je prvo radno mjesto $P R$ managera ustrojeno 1964. godine u zagrebačkom luksuznom hotelu Esplanade s primarnom zadaćom svjesne izgradnje odnosa između hotela i okruženja te utjecanje na okolinu. Stoga, iako nedostaju cjeloviti materijalni dokazi koji bi u potpunosti zadovoljili istraživače, tumači se da je upravo taj podatak početak profesije hrvatskih odnosa s javnošću (Tomić, 2008, str. 43; Jugo, 2012, str. 41). Zbog informacijskog deficita nije moguće precizno utvrditi u kojem je točno odjelu postojala osoba u Podravci koja je 1968. godine bila zadužena za odnose s javnošću. Skoko (2006, str. 15) prenosi kako je „navodno“ radila u sektoru za prodaju, a Tomić (2008, str. 45) raspolaže nešto konkretnijim podatkom o njezinom angažmanu u sklopu marketinškog sektora kroz sljedećih tridesetak godina, naglašavajući kako nije poznato tko je točno bio taj prvi djelatnik. No, tijekom cijelog su tog vremena izlazile novine „Podravka“ kao jedan od modela informiranja (Tomić, 2008, str. 45).

Razvoj odnosa s javnošću u Hrvatskoj je, smatra Zdeslav Milas (2011, str. 27), uvjetovan društvenim uređenjem. Naime, dok su se odnosi s javnošću u zapadnoj Europi mogli snažno razvijati, nedostatak demokratskog i pluralističkog sustava u Hrvatskoj, sve do 1990. godine, ograničavao je taj proces. Kao oblik javne komunikacije sveprisutna je bila propaganda te manipulacija kao njezin izrazito negativni element (Milas, 2011). S uspostavom demokratskog poretka stvaraju se i snažni preduvjeti za razvoj suvremenih, čak i državnih odnosa s javnošću koji nastaju 1990. osnivanjem Ministarstva informiranja, a od 1992. Ureda za odnose s javnošću Vlade Republike Hrvatske (Zakon, 1992; Milas, 2011, str. 28). Skoko (2006, str. 15) vidi to kao preteču današnjih ureda za odnose $s$ javnošću i glasnogovornika u vladinim institucijama i drugim javnim tijelima. Eduard Osredečki 1995. objavljuje prvu knjigu s područja odnosa s javnošću u Hrvatskoj, koji godinu ranije inicira i prvu strukovnu udrugu na nacionalnoj razini koja je registrirana 1998. kao Hrvatska udruga za odnose s javnošću. Dio međunarodne organizacije, potpisujući o tome akt s International Public Relations Association, postaje 2002. godine (HUOJ, 2016). Krajem devedesetih godina dvadesetog stoljeća u Hrvatskoj s radom započinju i prve agencije za odnose s javnošću. 


\section{Razvoj por
alktivinosti}

Iako okosnicu javnog linijskog prijevoza putnika danas čine autobusi i tramvaji, manje je poznato da uspinjača predstavlja prvo sredstvo organiziranog prijevoza u Zagrebu, čak godinu dana starije od konjskog tramvaja. Početak njezinog prometovanja kroz dostupnu se literaturu ponajprije dovodi u vezu s poteškoćama samog projekta, osobito tijekom izgradnje, a zatim i eksploatacije, nakon čega kroz prošlost predstavlja senzaciju, zahtijeva i doživljava modernizaciju, a u današnje se vrijeme ubraja među najprepoznatljivije gradske simbole. Informacije dostupne široj javnosti uglavnom ne otkrivaju više o prijevoznom sredstvu čija geneza u Zagrebu već tada, unatoč nepostojanju same profesije, sadrži elemente suvremenih upravljanja komunikacijama i odnosa s javnošću .

Današnja literatura koja promatra uspinjaču simplificira cijeli slučaj, govoreći o brzom „prihvaćanju projekta s oduševljenjem“ (Šobota, 2011, str. 145). Prvi se put u javnosti, kroz tadašnji tisak, spominje 9. listopada 1888. godine, u prvom izdanju novina, dan nakon što je gradski vijećnik Hudovski izvijestio na sjednici gradskog zastupstva Slobodnog i kraljevskog grada Zagreba o namjeri osječkog poduzetnika D. W. Kleina da uspinjačom poveže Gornji i Donji grad. Iz članka se sa sigurnošću može zaključiti da je o kapitalnom projektu pozitivno odlučeno samo dva dana od podnošenja zamolbe i to čak prije formalnog početka sjednice, odnosno izvan planiranog dnevnog reda (Narodne novine, 1888), što vrlo vjerojatno upućuje na prethodno lobiranje ${ }^{\prime}$. Nadalje, iz istog je zapisa (vidi sliku 1) razvidno kako je cijeli projekt detaljno razrađen, uključujući čak i cijene prijevoza, što upućuje na primjenu prvog koraka u planiranju, odnosno temeljitu analizu. Istraživanje s ciljem sagledavanja mikrookoline, društvenog okruženja i mogućnosti Cutlip sa sur. (2003, str. 340) naziva obavještajnim funkcijama koje su u slučaju uspinjače podrazumijevale i brojanje prolaznika uoči odabira lokacije na kojoj će se uspinjača izgraditi. Afirmativna prezentacija projekta kroz medije dodatno se potkrepljuje brojnim koristima za grad i zajednicu, naglašene su sve izravne, ali i sekundarne prednosti, čime se već tada ističe društveno odgovorno poslovanje. Naglasak je stavljen na sigurnosni aspekt te se za realizaciju projekta priprema isključivo pozitivno ozračje u javnosti. Zadaća je to, između ostalog, današnjih komunikacijskih procesa. Primjenjuju se i

1 Osredečki (1995, str. 101) lobiranje definira utjecanjem na odluke ili mišljenja, između ostalog, nekog vladajućeg ili korporativnog tijela, odnosno djelovanjem na predstavnike vlasti kako bi prihvatili i proveli odluke u interesu onoga tko lobira. 
načela razumljivosti poruke, što kasnije Kotler (1994, str. 711) preporučuje pri kodiranju poruke. Naime, široj javnosti bilo je nužno pojasniti o kakvom je prijevoznom sredstvu riječ pa se isprva uspinjača nazivala željeznicom na žicu, a tisak je, radi lakše predodžbe i razumijevanja koristio Zagrepčanima puno „bliži“ njemački termin Drahtseilbahn.

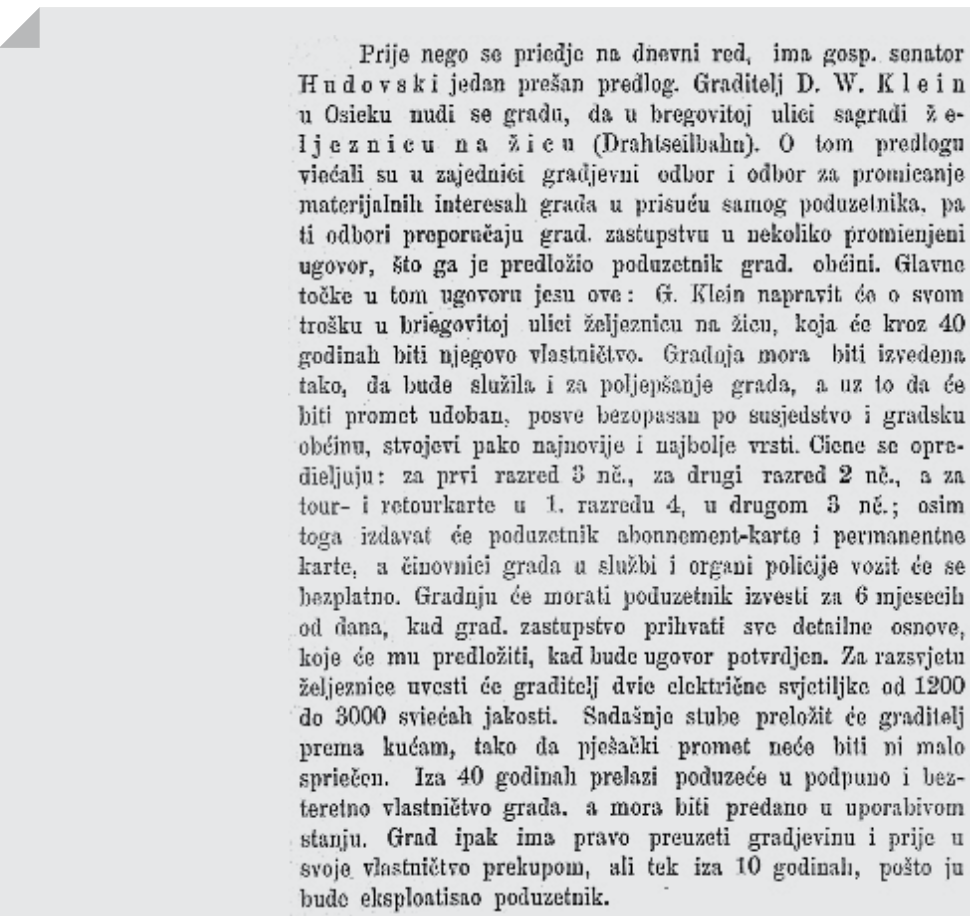

Slika 1. Prvi članak o uspinjači koji ukazuje na korištenje tehnika i alata odnosa s javnošću (Izvor: Narodne novine, 9. listopada 1888.)

Izuzmu li se sumnjičava i povremena pitanja gradskih zastupnika koja u medijima nisu zauzela značajniji prostor, procesi koji prethode praktičnoj izgradnji uspinjače teku bez poteškoća, za što su zaslužni komunikacijski utjecaji na javnost. I samo potpisivanje ugovora o izgradnji praćeno je isključivo pozitivnim napisima: „Promet u Zagrebu. Gradsko zastupstvo zaključilo je na ponudu poduzetnika g. Kleina u Osieku, da izgradi željeznički prevoz u Bregovitoj ulici. Ovaj prevoz bit će valjda do travnja gotov, te će se onda mnogo laglje i brže moći iz doljnjega grada u gornji i obratno. Vozarina bit će vrlo umjerena. Novine domaće pišu..."(Dom i sviet, 1.11.1888.). 
Utjecaj na pozitivan imidž uspinjače ima i članak objavljen mjesec dana kasnije u kojemu se detaljno prenosi objava poduzetnika koja sadrži informacije po kojim ulicama će se kretati „Željeznica“ te je opisano da će sagraditi „ukusan paviljon za putnike“, imati I. i II. razred, da cijeli sustav kao i „sve prostorije biti će električnim svjetlom razsvietljene“ te kolika je cijena vožnje (Narodne novine, 21.12.1888.).

Odnosi s medijima također se vrlo snažno demonstriraju 1889. godine tijekom nastajanja zagrebačke uspinjače. Aljinović (ZET, 2005) navodi kako su se kućevlasnici u zoni Bregovite ulice, gdje su počeli graditi uspinjaču, suprotstavili projektu tijekom pripremnih građevinskih aktivnosti. S ciljem kontrole situacije i javnosti na mjesto prosvjeda dolazi posebno povjerenstvo praćeno naoružanim gradskim stražarima kako bi se suprotstavljenu javnost „uvjerilo“ da izgradnja uspinjače neće biti na njihovu štetu. Novine u prvom sljedećem izdanju objavljuju: „Povjerenstvo je sve točno pregledalo, pa uvjerilo dotične vlasnike da neće samo neštetovati, već upravo veliku korist crpiti iz tog projekta. Sada više ništa nije na putu da se taj projekt izvede.“ (ZET, 2005)

U odnosima s javnošću koji se provode uz uspinjaču korišteni su i drugi tada dostupni alati. Službeni početak radova prati izlaganje nacrta uspinjače u Ilici (ZET, 2005) iz čega se može zaključiti da se na javnost utječe i vizualnim tehnikama. Naime, dnevne novine, kako je vidljivo iz dostupnih arhivskih izvora, $\mathrm{u}$ tom vremenu nisu prenosile skice ili fotografske zapise.

Demanti, kao novinarski žanr kojim se, pojavljuje se također u kontekstu uspinjače, što dodatno i bez sumnje još tada potvrđuje korištenje tehnika odnosa s javnošću. List Obzor 14. travnja 1890. objavljuje senzacionalističku vijest o nesreći tijekom pokusne vožnje pri čemu je, kako piše, „pukao zavor“, odnosno dio sigurnosnog sustava koji osigurava od veće nesreće u slučaju puknuća žice. Dan kasnije, 15. travnja 1890. objavljen je ispravak vijesti i u Obzoru i u drugim dnevnim novinama (vidi sliku 2), što jasno upućuje na organizirano djelovanje odnosa s javnošću. Obzor kroz ispravak donosi pozitivnu vijest, objavljujući kako se nije dogodila nesreća, nego uspješan pokus. 
- (U z p in j a č a.) Izaslanik makinske trornice Ganz i dr. iz Budimpešte radi ozbiljno o instalaciji nesretne uzpiajače u bregovitoj ulici. Jučer su ěinjeni po danu i na večer pri elektriěnom svjetlu pokusi vožnje s obterećenimi vagoni. U vagone uzeto je toliko vrećah kamenja, koliko odgovara težini ljudih, koji imadu mjesta u vagonih. Kako nam se jarlja, nije izpravns viest juと̌erašnjeg jednog lista, da je pri pokusu pulkao „zavor“, kojim bi se sustavio "vlak“, kad bi nesretnim sluěajem puklo uže od žice. Inžinier tvornice radi baš o instalaciji toga nzsvora ${ }^{4}$, pa ga je dao odšarafiti, $i$ on je u tom povodu pao, a nije pukao. Kad ée uzpinjačs biti podpuno gotova tako, da bi se - ako grad. poglavarstvo dozvoli - mogla predati prometu, nije nam poznato. Sutra u 4 sata imat će odbor grad. zastupstva za uzpinjaču sjednicu, u kojoj će izrjestitelj dr. V. pl. Nikolić podastrieti svoj izvještaj, pa će se to pitanje raljda u budućoj sjednici grad. poglavarstva konačno riešiti.

Slika 2. Prvi demanti o javnom prijevozu u dnevnom tisku (Izvor: Narodne novine, 15.4.1890.)

Informacije off the record, kojima i danas obiluje novinarska praksa, primjećujemo također već uz projekt uspinjače kao rezultat izravnih odnosa s novinarima. Kako je vidljivo iz dnevnog tiska, Obzor još u svibnju 1889. objavljuje informacije ne navodeći pritom izvor blizak Gradu ili investitoru. Novinaru je pružena ekskluzivna vijest, dok izvor istovremeno koristi medijski prostor za željenu poruku, što predstavlja obostrani interes: „(Parna uzpinjača) započeti će se graditi, kako iz pouzdana izvora čujemo, početkom drugog tjedna. Radnje su zadocnile, jer je valjalo spreme iz tvornica naručiti, te se je čekalo, dok bude bar jedan dio tih sprema gotov.“ (Obzor, 16.5.1889.)

Odnosi s javnošću, zbog poteškoća u realizaciji projekta, bili su od iznimne važnosti, no iako su se pojedine taktike provodile intenzivno, nisu tada bili strateški organizirani. Zbog toga, kao i opsežnih problema u projektu s vremenom je izgubljena kontrola nad upravljanjem javnim mišljenjem pa je uspinjača imala razdoblja sasvim negativnih konotacija.

Tramvaj se u Zagrebu prvi put, prema dostupnim zapisima, najavljuje u listopadu 1884. godine, odnosno četiri godine prije nego što se govorilo o uspinjači i čak sedam godina uoči realizacije samog projekta. O tome svjedoči i objava u Narodnim novinama, 25. listopada 1884. godine:

„Medju najnovije novosti može se uvrstiti i ta, da će i Zagreb dobiti Tramvay, koji već ima glavni grad i Bosne i Slavonije. Ako se obistini namjera nudioca, oživotvorit će se taj podhvat već početkom svibnja buduće godine. Koliko će god takova udobna i jeftina 
'prilika' biti obćinstvu ugodna, toliko će naši fijakeri i omnibusi poprieko gledati opasnu konkurenciju, jer će se svatko k svakom vlakom dovezti se samo za nekoliko novčićah.“”

Za razliku od komunikacijskih aktivnosti i upravljanja u odnosima s javnošću koja su pratila uspinjaču, implementacija tramvaja niti u jednoj fazi nije uključivala značajnija organizirana komunikacijska djelovanja. Tisak je prenosio tek povremene bilješke s gradskih sjednica, nacrte ugovora te u kasnijoj fazi odredbe koje su regulirale novi model prijevoza, uglavnom u birokratskoj formi. Unatoč velikoj važnosti tramvaja za grad, osim u stručnim krugovima, tramvaj nije izazivao poseban interes javnosti tijekom razvoja, sve do prve vožnje u rujnu 1891. godine, no ipak je zabilježena komunikacijska praksa koja se do tada nije pojavljivala u kontekstu javnog linijskog prijevoza putnika. Tako se 9. prosinca 1884. godine raspisuje, a ubrzo objavljuje u novinama tzv. ,jeftimba“, ponudbena rasprava (vidi sliku 3), format koji predstavlja današnji javni poziv, odnosno natječaj.

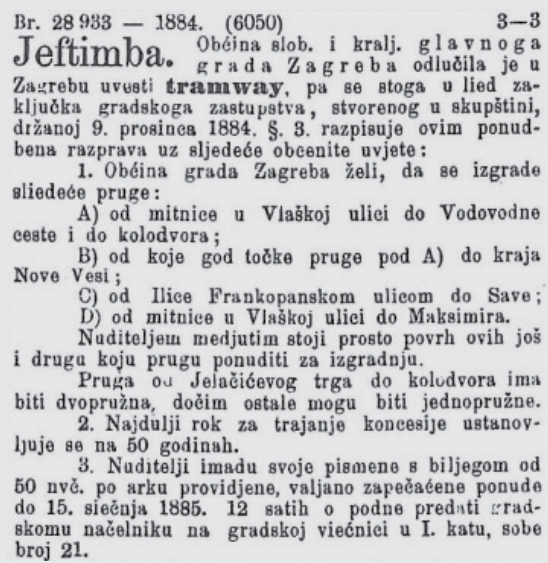

Na kasnije stigle ponude neće se obzir uzeti. 4. U ponudi ima biti toèno naznačeno u kojern vremenu, kojim redom $i$ pod kojimi uvjeti će nuditelji gore spomenute pruge izgraditi.

5. Nuditelj ima potanko naznačiti eienik, po kojem ée voziti.

6. U ponudi se ima naznačiti, da li će se podhvat tjerati \& konji ili 8 parom, ili mješovito - nu promet u Ilici i Novoj Vesi nesmije se za sada tjerati 8 parom.

7. Ponudi se ima priložiti bud u vriednostnih papirih, prıkladnih za jamčevinu, bud u gotovom vadij od 5000 for., slovi pet hiljadah for. a. vr. ili psko potvrda gradske blagajne o tom, da je vadij kod nje pohranjen.

8. Vadij se ims prigodom sklapanja ugovora nadopuniti tao iamčevine na 10.000 for., slovi deset hiljadah for. a. vr.

9. 0 prihvatu ponudah odlučuje gradsko zastupstvo nepazec na pogodnosti, pa może i sve ponude odbiti.

10. Potanje uvjete, koji imadu služiti temeljem ugovoru mogu nuditelji uviditi za uredovnog vremena poěam od 2 siešnja 1885. na gradekoj vieéniei u I. lratu, sobe br. 16.

U Zagrebu, 17. prosines 1884.

Gradsko poglavarstvo.

Gradski načelnik : D r. H o f m a n.

Slika 3. Objava prvog javnog natječaja u zagrebačkom javnom prijevozu (Izvor: Narodne novine, 31. prosinca 1884.)

Na slabiju medijsku zastupljenost zagrebačkog tramvaja u javnosti svakako utječe činjenica da je takav model prijevoznog sredstva već bio prisutan u drugim regionalnim centrima, primjerice u Osijeku od 1884. (GPP Osijek, 2016) te u Sarajevu od 1885. godine. Međutim, kao i danas, zbog svojeg značaja za zajednicu predstavlja jedan od prioriteta lokalnih vlasti, 
zbog čega se često koristi u kontekstu političkog komuniciranja, tim više što utječe na imidž, odnosno reputaciju sredine, što već tada, pozivajući se na javno mnijenje, ističe dnevni tisak: „bilo bi već jednom vrieme, da se radi ugleda glavnog grada i njegovog zastupstva zadovolji javnomu mnienju.“(Obzor, 12.4.1889).

Dva mjeseca uoči puštanja u promet prvog konjskog tramvaja, nakon medijskih objava koje su se godinama većinom odnosile na buduće trase linija i vlasničku strukturu samog društva, objavljuje se rasprava o završnim cijenama prijevoznih usluga s gradske sjednice. Prve informacije koje su primarno namijenjene masovnom komuniciranju u svrhu informiranja o novom prijevoznom sredstvu uobličene su u „posebne odredbe“ koje tisak objavljuje 3. rujna 1891. uoči puštanja tramvaja u promet:

„(Zagrebački tramway.) Pošto će se 5. ili 6. o. mj. predati zagrebački tramway prometu, izdane su $u$ interesu prometne i osobne sigurnosti ove odredbe:

1. Tramwaysku prugu nije slobodno ničim zapremiti, naročito nesmije se na prugu ostavljati nikakovih predmetah niti upregnutih kolah bez nadzora.

2. Tramwayskim kolima imadu se ugibati na dovoljnu širinu svi vozovi bez razlike.

3. Ulaz u kola dozvoljen je samo na onih mjestih, na..." (Narodne novine, 3.9.1891).

Prvo organizirano informiranje ciljne javnosti o tramvajskom prometu u Zagrebu predstavlja 1864. godine izdavanje, a zatim raspačavanje zasebne publikacije temeljene na tim odredbama s pravilima prijevoza i praktičnim savjetima, posebice sigurnosnim, za putnike i građane općenito. Nedostatak organiziranih odnosa s javnošću u praksi javnog prijevoza razvidan je iz medijskih objava koje se odnose uglavnom na tehničke ili negativne događaje u javnom prijevozu (vidi sliku 4), osobito nakon elektrifikacije tramvaja što čak do danas utječe na organizacijsku reputaciju. 

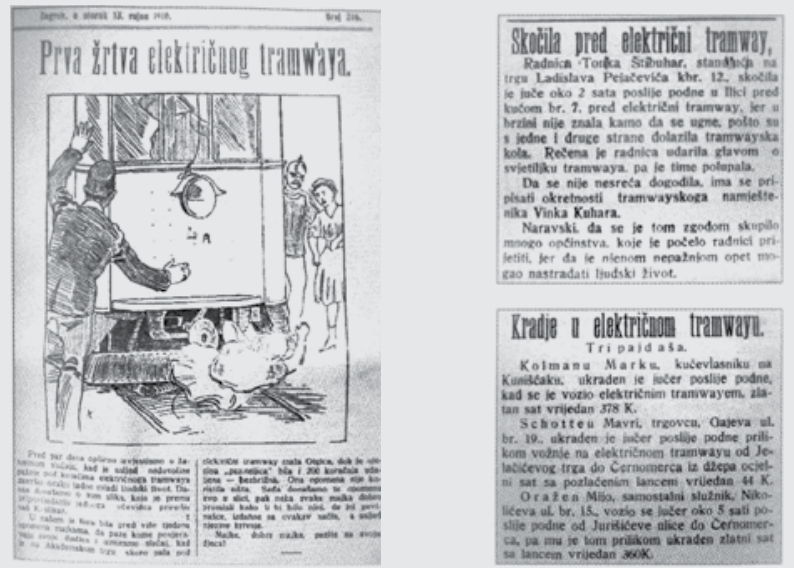

Slika 4. Negativni medijski napisi o tramvajskom prijevozu (Izvor: Bijelić, 2011, str. 55-56)

Upravljanje odnosima s javnošću zasigurno u najvećoj mjeri nedostaje tijekom potrebe kriznog komuniciranja javnog prijevoznika zbog teške prometne nesreće na mirogojskoj pruzi 31. listopada 1954. godine kada je 19 osoba izgubilo život, a 37 ih je bilo teško ozlijeđeno.
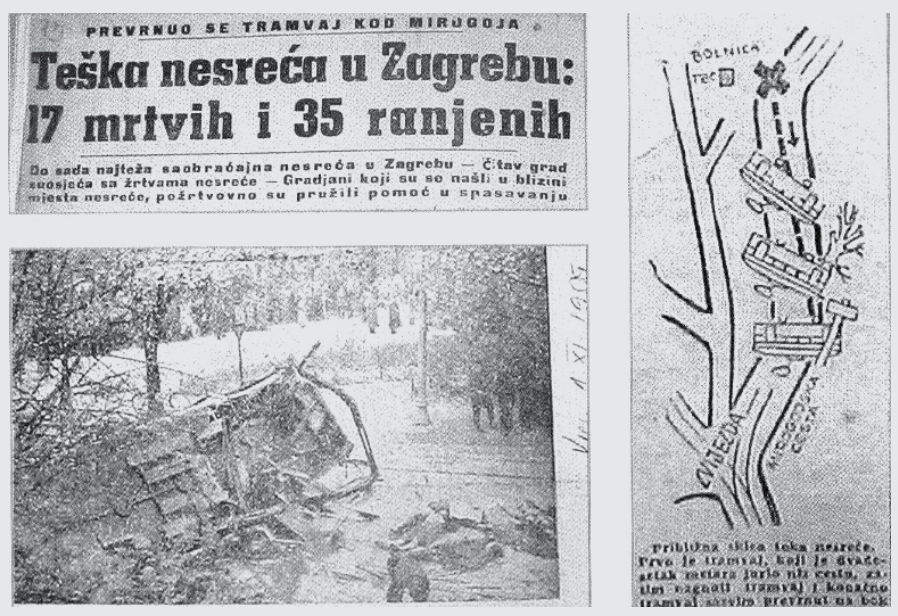

Slika 5. Teška tramvajska nesreća (Izvor: Foto arhiv ZET-a, Vjesnik, 1. studenoga 1954.) 
Tisak je prenosio vijesti o stradalima i samom događaju, a konferenciju za medije održao je načelnik tadašnje Uprave unutrašnjih poslova, iznoseći zaključke očevida i dovodeći vozača i organizaciju (ZET) u izravnu odgovornost.

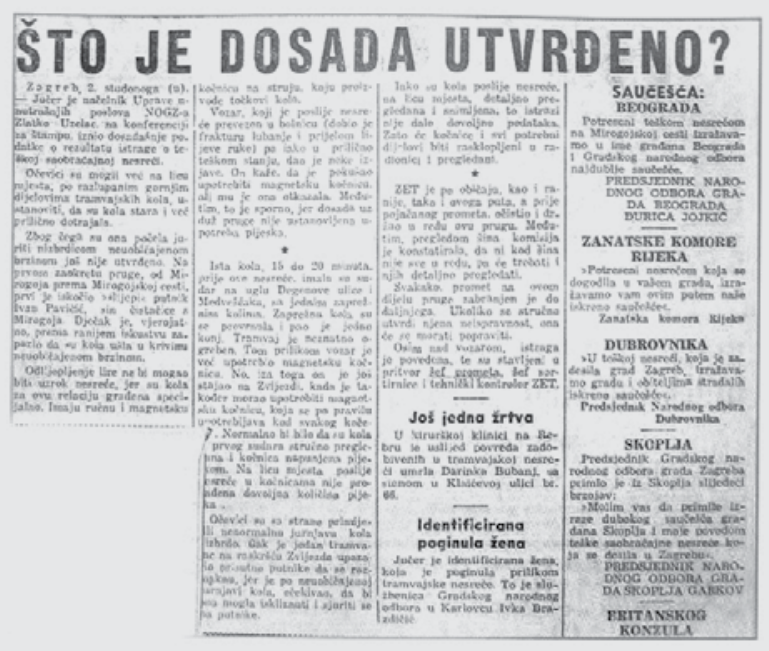

Slika 6. Konferencija za novinare, 2. 11. 1954 (Izvor: Bijelić, 2011, str. 102)

Iako se odnosima s javnošću nije upravljalo i realizirali su se nesvjesno kroz prometno osoblje, zanimljivo je organizirano marketinško komuniciranje u putničkim prostorima vozila javnog prijevoza već u 1930-im godinama (Bijelić, 2011, str. 58). Bilježe se oblici oglašavanja kakvi postoje i danas, a ono je, kako tvrdi Tomić (2008, str. 62) informacija koju plasira poznati naručitelj, plaćajući prostor i vrijeme oglašavanja. Iz toga proizlazi kako je interijer vozila javnog prijevoza vrlo rano prepoznat kao svojevrstan i atraktivan medijski prostor koji se komercijalizira za potrebe kontroliranih promidžbenih aktivnosti.

\section{Organizirani modeli informiranja}

Iako je Zagrebački električni tramvaj kroz prošlost i vrlo dugo od utemeljenja neznatnu pozornost pridavao odnosima s medijima i eksternoj javnošću općenito, internim se komuniciranjem pozicionirao na sami početak prakse korporativnog informiranja. Kako je ranije u ovom radu 
i navedeno, početak razvoja odnosa s javnošću u Hrvatskoj veže se uz turističku djelatnost i 1964. godinu kada je, navodno i u nedostatku potpunih službenih dokaza, ustrojeno radno mjesto za djelatnika kojemu je zadaća bila stvaranje boljih odnosa između hotela Esplanade i okruženja. U gospodarskom sektoru također nedostaju detaljni podaci koji bi sa sigurnošću potvrdili početak formalnih odnosa s javnošću. Smatra se kako je prva s informiranjem započela Podravka 1968. godine kroz marketinški sektor, objavljujući novine „Podravka“ i aktivnosti još uvijek nepoznate osobe koja je obavljala poslove odnosa s javnošću. Manje je poznato kako Zagrebački električni tramvaj u travnju 1959. godine (vidi sliku 7) započinje izdavati novine, čak devet godina prije Podravke i tri mjeseca prije Večernjeg lista. U uvodnom tekstu prvoga broja obrazlaže se ustrojstvo komunikacijskog kanala:

„Današnji tempo života traži potpunog čovjeka, koji mora poznavati prilike u kojima živi kao i sredstva s kojim raspolaže. Jedno od važnih sredstava u takvom radu jest štampa, preko koje čovjek obogaćuje svoja iskustva i kritički posmatra pojedine događaje. Radnički savjet na svojoj sjednici 6. II. 1959. donio je prema tome zaključak, da se pristupi izdavanju (...)“ (Bilten, 1959).

Uredništvo novine klasificira kao „informativno-savjetodavno“ glasilo kolektiva. Najprije brojevi izlaze u formatu 20,5 x 14,5 centimetara na 24 stranice i u nakladi od 500 primjeraka.

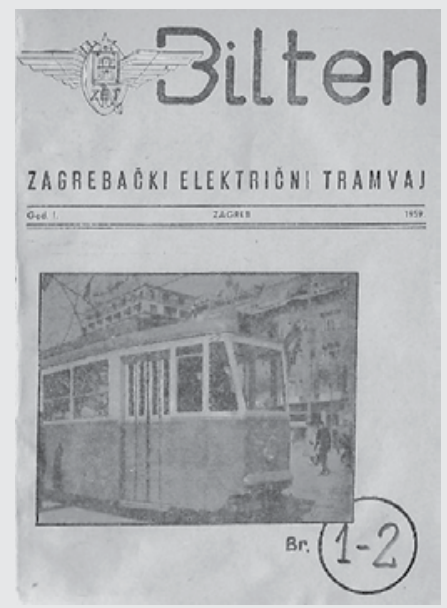

KUPUJTE, CITAJTE I SIRITE NASE GLASILOI

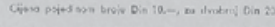

Naslovnica prvog broja ZET-ovih novina, 1.4.1959. (Izvor: Bilten, 1959) 
Prva izdanja ZET-ovih novina umnožavala su se na vlastitom stroju, cijena mjesečnika bila je istovjetna cijeni dnevnih novina, a dvobroj se naplaćivao dvostruko. Vrlo brzo se zaključuje kako format novina, naziv i naklada ne odgovaraju sadržaju i komunikacijskim potrebama. Samo godinu dana kasnije, 1. travnja 1960. godine novine se počinju tiskati u tiskari s udvostručenom nakladom, a izvorni naziv „Bilten Zagrebačkog električnog tramvaja“ zamjenjuje se naslovom „Vjesnik - ZET“.

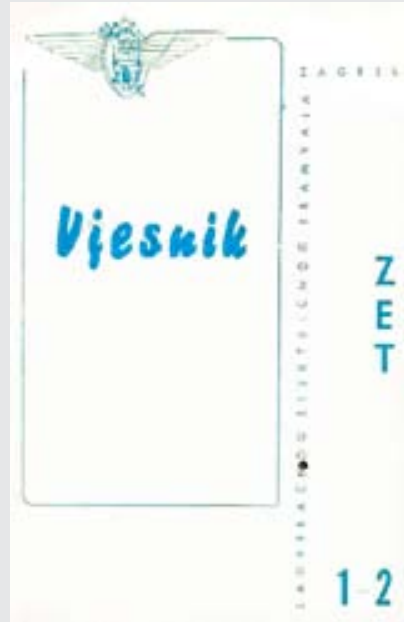

Slika 8. Naslovnica novina Vjesnik ZET, 1960. (Izvor: Arhiv ZET-a)

Novine zbog štednje nisu objavljivale fotografije, a u početku se novinarskom i uređivačkom poslu pristupalo amaterski. U prve četiri godine list je objavljivao tekstove čak više od 80 različitih autora te 15 stranih suradnika, stručnjaka iz sedam zemalja, nakon čega se mreža dopisnika širi na sve kontinente koji su izvještavali o javnom prijevozu diljem svijeta. Istovremeno, autori iz Zagrebačkog električnog tramvaja pisali su tekstove za izdanja novina u drugim državama (Benažić, 1981, str. 90). Iako su izdanja novina od 1959. do 1962. imala glavnog urednika Zvonka Rehorića, kako je vidljivo iz impresuma, 1. studenog 1962. uređivanje lista preuzima profesionalni novinar Mario Bazina te se osniva jedna od prvih profesionalnih informativnih službi u zemljama regije. Informativna služba utemeljena je 1964. godine. Naklada lista dostiže 6.300 primjeraka, a osim trenutnih i umirovljenih radnika, zaprimaju ga svi zainteresirani pojedinci, drugi pravni subjekti i mediji, čime nadilazi izvorni koncept internog informiranja (Benažić, 1981). Izlazio je sve do prosinca 2008. godine. 
Mjesečnik nije mogao zadovoljiti informacijsku potražnju, dinamiku događaja na razini kolektiva, novosti na području javnog prijevoza te društvenog života pa se 1966. javlja potreba za izdavanjem dodatnog glasila. Započinje izlaziti tjedni bilten koji se distribuira na jednaki način kao i novine. U arhivu nisu dostupna izdanja starija od 1967. godine, iako se redovno tiskao do 2014. godine, a u slučaju potrebe izlazi i danas.

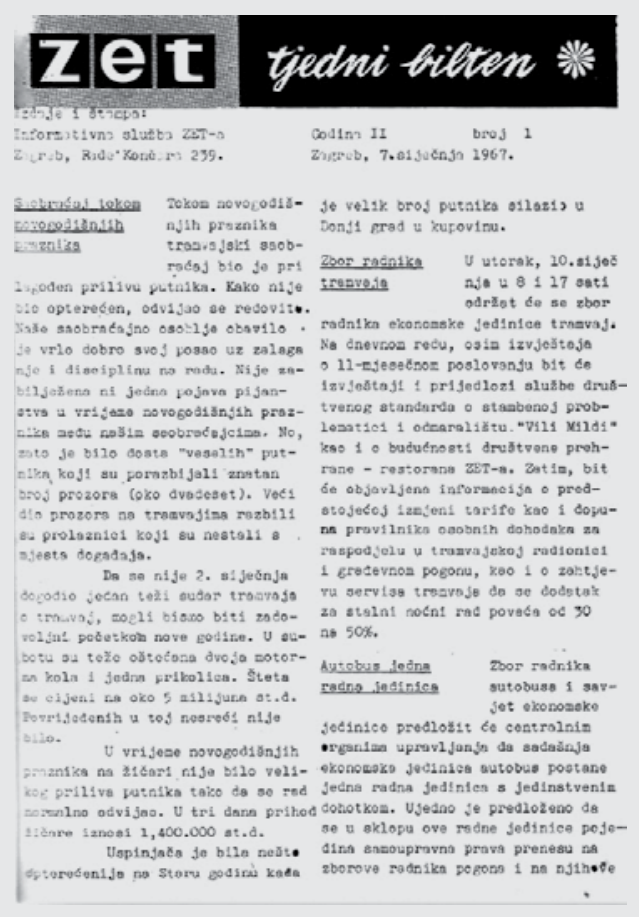

Interne komunikacijske aktivnosti zagrebačkog javnog prijevoznika bile su intenzivne, obuhvaćale su i foto-novine, oglasne ploče i ploče s ekonomskim pokazateljima, program putem razglasa te prigodne tiskovine (Benažić, 1981), ali je informiranje bilo kontrolirano. U posebnoj tiskovini izdanoj u povodu 90. obljetnice ZET-a, 1981. godine, koja je zamijenila uobičajeni broj novina, uredništvo, između ostalog, navodi: „Nad informiranjem, kao dijelu javnosti rada samoupravnih organa i rada i života kolektiva, posebnu brigu vodi odbor, odnosno 
Komisija za obavještavanje RS ZET-a.“ (Benažić, 1981) U istoj publikaciji prenosi i fotografiju iz šezdesetih godina 20. stoljeća koju opisuje nadzorom nad informiranjem nadležne Komisije, iz čega se može zaključiti da su postojala tijela zadužena za usmjeravanje komunikacijskih procesa (Benažić, 1981). Za razliku od organiziranog internog informiranja, komunikacijske aktivnosti Službe za informiranje uglavnom nisu obuhvaćale eksternu javnost. Informiranje se odnosilo na operativne prometne obavijesti, provodilo se na terenu i većinom kroz prometne djelatnike, a „komunikacijski kanal“ ili „medij“ bila su vozila ZET-a s razglasom na krovu automobila uz trasu linija (Foto arhiv ZET-a, n.p.).

\section{Surremene tehnike i alati}

Interakciju s javnošću i korištenje povratnih informacija svojih cilinih javnosti, što podrazumijeva dvosmjerni asimetrični model (Milas, 2011, str. 47), Zagrebački električni tramvaj uvodi prilično kasno, 2007. godine promjenom principa u radu resornog Ureda. S namjerom poticanja dijaloga uvodi besplatnu telefonsku liniju za komunikaciju s građanima te o tome izvješćuje javnost. Mediji isti dan prenose priopćenje o mogućnosti komunikacije s organizacijom, no iz tih se objava zaključuje njezina izrazito negativna reputacija. Tako, između ostalih, dnevnik 24 sata, 21. lipnja 2007. godine objavljuje:

„Bahate ZET-ovce građani će od sada moći prijaviti na besplatan broj telefona 0800 200 060. Pritom je vrlo važno zapamtiti broj linije i vozila jer se prema voznom redu utvrđuje identitet bahatih vozača. Tada se pokreće postupak odgovornosti i ako se utvrdi krivnja, stegovni postupak. Tako bi bezobrazno ponašanje pojedinih vozača i kontrolora u tramvajima i autobusima trebalo biti prošlost, prenose jedne dnevne novine.“

Interakciji s javnošću se u početku protive pojedine sindikalne organizacije, no zahtjevi javnosti uvjetuju daljnji razvoj komunikacijskog alata. Tako je 29. svibnja 2009. pokrenut prvi Kontakt centar ZET-a, uz podršku Uprave Društva i tijela lokalnih vlasti (Zagreb, 2009). Linije postaju dostupne u svim izvanrednim okolnostima (Tportal, 2014), a 2015. godine komunikacijska se praksa proširuje na druge podružnice u sastavu Društva. U studenom 2015. godine otvara se jedinstveni pozivni centar Zagrebačkog holdinga, a iskorak $\mathrm{u}$ odnosima $\mathrm{s}$ javnošću predstavljen na konferenciji za novinare u javnosti izaziva sumnju. O tome svjedoči i novinarsko istraživanje Večernjeg lista provedeno dva mjeseca poslije službenog otvorenja Pozivnog centra, nakon čega Šobak (2016) piše: 
„Dva mjeseca prošlo je od uspostavljanja call-centra Holdinga. - Ne uspijemo li vam se javiti kad nazovete da iznesete svoj problem, mi ćemo vas nazvati povratno, da nam ipak kažete što vas muči - uvjeravali su djelatnici call-centra prije dva mjeseca kada je Holding počeo svoj projekt. Više od šezdeset dana, pomislili smo, dobar je rok za 'uhodavanje', pa smo kolega Stjepan Bubalo i ja odlučili isprobati 'pali’ li obećana taktika. Nazvali smo ukupno šest puta, ljubazne odgovore dobili u pet slučajeva, dok su nas jednom, kad se u call-centru nitko nije javio, nazvali povratno. Priznajem, iz pozivnog centra Holdinga iznenadili su nas jer, kako to obično biva u novinarskoj maniri, kolega Bubalo i ja očekivali smo tišinu s druge strane linije, a usto, još veću kad je riječ o povratnom pozivu. Odlična će nam to biti tema o slabom funkcioniranju Holdingova pozivnog centra, pomislili smo. Činjenica, pak, da ga jednostavno moramo pohvaliti čak nas je ovog puta još više razveselila budući da je i nas same vrlo ugodno iznenadila.“

Pozivni centar i formalno je pozicioniran kao organizacijska jedinica u Direkciji Zagrebačkog holdinga, dostupan je 24 sata dnevno sve dane u godini, a koristi najsuvremenije informatičke platforme za komunikaciju. Na pozive odgovaraju i predstavnici menadžmenta u posebnom terminu, prema rasporedu objavljenom u medijima (Godišnje izvješće, 2016).

Internetska komunikacija Zagrebačkog električnog tramvaja također je do 2007. godine bila ograničena. Stranica je podrazumijevala poveznice za preuzimanje tekstualnih dokumenata koji su sadržavali jednostavnije prometne obavijesti, a nije redovito ažurirana. Na konferenciji za novinare 22. studenog 2007. javnosti je predstavljena stranica koja je u skladu s tadašnjim standardima mrežne prezentacije omogućavala autonomno uređivanje, što je zbog prirode prijevozničke djelatnosti i dinamičnog okruženja od iznimne važnosti. Prvi se put omogućuje pregled aktualne prometne situacije, a Vjesnik (2007) bilježi:

„Internetska stranica Zagrebačkog električnog tramvaja, www.zet.hr, od jučer je u novom ruhu. Iako njezin sadašnji oblik nije konačan, među informacijama su dnevni i noćni vozni redovi tramvaja i autobusa te povijesti ZET-a. Stranica će se puniti i novim informacijama o stanju u prometu. -Želimo što bolje odnose s građanima pa će stranica, osima tekstova, nalaziti video i audio zapisi. Stranica će olakšati posao i vozačima, koji će na internetu moći provjeravati raspored smjena i stanje u prometu.“

Stvoren je tako i novi kanal interne komunikacije, odnosno zasebna internetska stranica namijenjena svakodnevnom internom komuniciranju organizacije s internom javnošću. Kako 
je internetska platforma omogućila multimedijske sadržaje, razvijajući odnose s medijima, ZET provodi proaktivne strategije, osiguravajući dostupnost medijskih objava u različitim formatima, a prema standardima profesionalnih elektroničkih medija. Tijekom 2014. godine, nakon potpisivanja ugovora o partnerstvu s renomiranom tvrtkom Google te intenzivnih aktivnosti na području informacijske prilagodbe, proširuju se internetski servisi te u listopadu postaju dostupni na novom internetskom sučelju. Zagrebačka novinska agencija (2014) tada prenosi:

„Zagrebački javni prijevoz tramvajima, autobusima i uspinjačom od danas je vidljiv praktični u cijelom svijetu zahvaljujući novim internetskim stranicama Zagrebačkog električnog tramvaja (ZET) s Google kartama (Google maps) i uvrštenju Zagreba u uslugu Google Transit koja korisnicima omogućava lakše informiranje o javnom prijevozu i planiranje putovanja po gradovima. Time se Zagreb našao među 2.800 gradova u svijetu koji su uvršteni u Google Transit (prometne informacije o javnom i drugim vrstama prijevoza s detaljnim kartama i uputama kako doći do odredišta), a usluga je rezultat suradnje ZET-a i regionalnog ureda Googlea za regiju Adriatic.“

Poseban dio internetske stranice rezerviran je za medije. Uz autorizirani pristup, novinari mogu preuzimati sve relevantne informacije, materijale različitih formata te zaprimati obavijesti u elektroničkom obliku.

Nakon što su stvorene sve pretpostavke za pravovremeno komuniciranje s javnošću putem masovnih medija te izravno, uz suvremene alate i tehnike, ZET uočava problem promptne distribucije poruka putnicima, kao ciljnoj javnosti tijekom samoga putovanja kada primatelji nisu izloženi sredstvima javnog priopćavanja. Uzevši u obzir značajke prometa kao izuzetno promjenjive i nepredvidive sredine $u$ kojoj prijevoznik realizira temeljnu djelatnost i na koju utječe niz faktora, u svibnju 2011. započelo se s preinakama postojeće infrastrukture, čime je omogućeno emitiranje zvučnog sadržaja istovremeno i uživo u putničkim prostorima svih vozila. Eksperimentalna emitiranja obuhvaćala su obavijesti o stanju u prometu, alternativnim pravcima tijekom zastoja, izvanrednim prometnim organizacijama i druge servisne informacije. Opremaju se studio i reportažna kola te se prvi put koriste 3. lipnja 2011. godine uoči posjeta Pape Benedikta XVI. Zagrebu. Iz studija se emitiraju vijesti za hodočasnike na hrvatskom, engleskom, njemačkom i talijanskom jeziku, a cijeli se posjet kroz sljedeća tri dana prati izravnim reporterskim javljanjima. Najavila je to i Informativna katolička agencija, a prenijele i druge svjetske novinske agencije: 
„Putnici će korisne informacije o regulaciji prometa, stanju na područjima posebne prometne organizacije i trasi kojom će prolaziti papa Benedikt XVI. moći čuti u posebnom internom programu koji će se emitirati u svim vozilima uživo, uz javljanja reportera s terena i povremeni prijenos dijelova programa Hrvatskog radija, osobito redakcije Radio Sljemena. Zbog hodočasnika iz drugih zemalja, servisne informacije objavljivat će se, sukladno potrebama, osim na hrvatskom, na engleskom, njemačkom i talijanskom jeziku. Iz posebno prilagođenog kombi vozila, iz kojega će se uključivati reporteri u spomenuti interni informativni program, zainteresiranim će se redakcijama slati izvještaji uz privitke: tonske izjave i fotografije, a dio materijala, onaj aktualan, moći će se preuzeti i na službenoj mrežnoj stranici ZET-a koja će se neprestano ažurirati.“ (IKA, 2011)

S obzirom na pozitivne efekte i doseg, inovativni komunikacijski kanal ZET-a javnosti se službeno predstavlja u lipnju 2011. (Večernji list, 2011). Godinu dana kasnije modernizira se studijska tehnika, a 2013. i reportažno vozilo. Na temelju uzajamnog povjerenja koje ZET izgrađuje u odnosima s medijima, u rujnu 2013. godine realizirano je prvo izravno uključenje iz studija ZET-a u televizijski program vlastitom produkcijom i slikom visoke rezolucije putem optičke mreže, a u veljači 2014. iz reportažnih kola ZET-a (Matković, 2016). ZET 2016. proizvodi emisiju koja se emitira na lokalnoj televiziji, a radijski i televizijski studio koristi se od 2016. na razini cijeloga društva za izradu manjih audiovizualnih djela namijenjenih također emitiranju u televizijskom ili radijskom programu, internetu, društvenim mrežama te specijaliziranim sustavima (Zagrebački holding, 2016). Iako komunikacijski procesi Zagrebačkog električnog tramvaja prate tehnološki razvoj i suvremene trendove, struktura javnosti, koja obuhvaća cijeli spektar demografske, dobne i sociološke pripadnosti, zahtijeva zadržavanje i korištenje svih dostupnih kanala komunikacije. Tako se, unatoč informatizaciji i digitalizaciji, uz specijalizirane i specifične tehnike, zadržavaju i one pisane, govorne i vizualne.

Kako struka i nalaže, Služba komunikacija i marketinga, prema definiranom popisu, medijima dostavlja priopćenja, objave za javnost i druge korisne informacije. Izrada press clippinga, selekcije relevantnih medijskih objava o organizaciji danas je digitalizirana te je taj proces povjeren specijaliziranom poduzeću. Izdaju se godišnja izvješća i brošure, a u pisanim se

2 Pisane tehnike obuhvaćaju niz materijala koje organizacije koriste u komunikaciji s medijima i ostalim ciljnim javnostima. Govorne uključuju razgovor licem u lice i sve druge oblike izravnog kontakta kroz osobne pojedinačne ili grupne susrete, više ili manje formalne. Vizualne tehnike odnosa s javnošću podrazumijevaju fotografije, video izjave, zaslone, oglasne panoe i slične kanale, dok se u posljednju skupinu ubrajaju nove tehnologije, uglavnom temeljene na internetskoj mreži. (Jugo, 2012, str. 238-241) 
tehnikama, zbog specifičnosti uloge javnog prijevoznika te grada Zagreba kao turističke destinacije, sve intenzivnije koriste i druga pisma. Tako se, osim na latiničnom pismu i europskim jezicima, 2016. tiskaju brošure s praktičnim uputama, uvjetima prijevoza i cijenama na korejskom i japanskom jeziku (ZET, 2016).

Od govornih je tehnika široj javnosti najznačajnija komunikacija licem u lice, zbog čega se i dalje otvara sve više centara za izravnu, osobnu komunikaciju, dok se u odnosima s medijima provode kroz izjave, intervjue i konferencije. Sastanci, neslužbeni susreti, govori, telefonski razgovori i konferencije zastupljeniji su u internoj komunikaciji, a posebni događaji uključuju sve segmente interne i eksterne javnosti. Vizualne tehnike koriste se kao medijski nastupi, korporativni filmovi i prezentacije, ali i kroz specijalizirane uređaje kojima su vozila javnog prijevoza i prometni koridori opremljeni. Jedna od najdugovječnijih tehnika u javnom prijevozu upravo je vizualna, a odnosi se na pravila korporativnog odijevanja po čemu su djelatnici Zagrebačkog električnog tramvaja prepoznatljivi već 126 godina.

\section{Zalključalk}

$\mathrm{U}$ ovom se radu promatrao razvoj komunikacijske prakse $\mathrm{u}$ djelatnosti javnog prijevoza na području grada Zagreba, kroz njegove različite segmente, a koju, mijenjajući tijekom prošlog vremena pravni oblik, danas realizira organizacija Zagrebački električni tramvaj, donedavna podružnica Zagrebačkog holdinga d.o.o., tvrtka u stopostotnom vlasništvu Grada Zagreba.

Iako se početak prakse odnosa s javnošću u gospodarskom sektoru uglavnom povezuje $s$ američkim kontinentom i krajem 19. stoljeća, a uže u prometnoj djelatnosti s 1897. godinom i američkom željeznicom, pojedine se tehnike i alati upravljanja odnosa s javnošću ranije od toga ili istovremeno već intenzivno koriste na zagrebačkom području. Primjena taktika odnosa s javnošću registrirana je nedvojbeno uoči početka izgradnje i eksploatacije prvog modela organiziranog javnog prijevoza u Zagrebu - uspinjače. Stručna literatura početke odnosa s javnošću u Hrvatskoj povezuje s 1964. godinom kada je u području turističke djelatnosti utemeljeno prvo radno mjesto s primarnom zadaćom izgradnje boljeg ozračja između organizacije i njezinih javnosti, iako o tome nema službenih dokaza koji sa sigurnošću i precizno potvrđuju takvu tvrdnju. U prvim se većim korporacijama na području Hrvatske razvoj odnosa s javnošću dovodi u vezu s prehrambenom industrijom, godinom 1968.i marketinškim 
odjelom koji započinje s provedbom internog informiranja kroz službeno glasilo, iako i u tome postoji informacijski deficit zbog kojeg se praksa ne može precizno utvrditi.

Analizom vjerodostojnih medijskih i internih zapisa o modelima javnog prijevoza koji danas djeluju u okvirima organizacije Zagrebački električni tramvaj, nepobitno se potvrđuje aktivna primjena alata, tehnika i pojedinih kategorija odnosa s javnošću prije godina koje se smatraju referentnim u utemeljenju današnje suvremene prakse (Jurić, 2016).

Tijekom stvaranja administrativnih preduvjeta za izgradnju uspinjače 1888. i 1889. godine iz zapisa se prepoznaju prva korištenja pojedinih tehnika, alata i novinarskih žanrova u djelatnosti javnog prijevoza. Ponajprije se identificira lobiranje kojem je prethodila aktivna analiza kao prvi korak u planiranju te intenzivne obavještajne funkcije tadašnje organizacije. Prvi komunikacijski procesi naglašavaju društveno odgovorno poslovanje, a u kodiranje poruka, osobito zbog utjecaja germanizma, odmah su uvedena načela razumljivosti. U odnosima s medijima, na koje intenzivno utječe lokalna politika, registriran je prvi demanti te distribucija off the record informacija.

Iako su alati i tehnike korištene intenzivno, uz brojne taktike, odnosi s javnošću nisu bili strateški organizirani. S obzirom na to da tramvaj nije nailazio na otpor u javnosti, uoči početka tog oblika javnog linijskog prijevoza nije postojala značajnija potreba za utjecaj na javno mnijenje pa su tako odnosi s javnošću izostali sve do njegova puštanja u promet. Masovno informiranje javnosti o tramvaju kao novom prijevoznom sredstvu provedeno je objavljivanjem posebnih odredbi o načinu i uvjetima korištenja vozila, ponajprije kroz dnevni tisak, a zatim izdavanjem prve publikacije koja se distribuirala građanima. Odnosi s eksternom javnošću gotovo se i ne provode sljedećih 116 godina te su indirektno povjereni prometnom osoblju koje te odgovorne funkcije nije bilo niti svjesno. To je dugoročno rezultiralo negativnom reputacijom organizacije. Unatoč nedostatku organiziranih odnosa s eksternom javnošću, tridesetih se godina 20. stoljeća već primjećuje prva marketinška komunikacija u javnom linijskom zagrebačkom prijevozu. Ipak, značajnu pažnju Zagrebački električni tramvaj počinje pridavati internom komuniciranju u travnju 1959. godine, devet godina prije Podravke. ZET tada počinje izdavati novine s jasno definiranom i poznatom uređivačkom politikom i strukturom, razvijajući čak i dopisničku mrežu, a 1962. osniva se profesionalna informativna služba (Jurić, 2016). Interna se komunikacija proširuje i drugim internim komunikacijskim kanalima, a primjetan je utjecaj političkog društvenog konteksta na uređivačku politiku, uz vrlo vjerojatnu cenzuru. 


\section{Suvremeni komunikacijski modeli s eksternom se javnošću javljaju prilično kasno, tek 2007. godine, no ranije nedostatno praćenje komunikacijskih trendova ubrzo se nadomješta inovativnim dostignućima. Tako Zagrebački električni tramvaj prvi uvodi vlastiti informativni govorni program u sva tramvajska i autobusna vozila te emitira program uživo iz studija i reportažnih kola, ovisno o potrebama, prometnim ili većim gradskim događajima.}

\section{Literatura}

- Benažić, B. i sur. (1981). Posebno revijalno izdanje lista „ZET“ u povodu 90. obljetnice ZET-a i 50. obljetnice autobusnog prometa u sastavu ZET-a. Zagreb: ZET d.o.o.

- Bernays, E. (1952). Public Relations. Norman: Oklahoma.

- Bijelić, D. (2011). Tramvaj u Zagrebu 1891-2011. Zagreb: Udruga vozača i automehaničara ZET-a.

- Bilten (1959). Zagrebački električni tramvaj, 1. Zagreb: Arhiv ZET-a.

- Cutlip, S. M., Center, A. H., Broom, G. M. (2003). Odnosi s javnošću. Zagreb: Mate.

- Fawkes, J. (2008). Što su odnosi s javnošću? U: Theaker, A. (ur.), Priručnik za odnose s javnošću. Zagreb: HUOJ.

- Grunig, J. E., Hunt, T. E. (1984). Managing Public Relations. New York: Holt, Reinhart \& Winston.

- Jurić, T. (2016). Razvoj komunikacijske prakse u sustavu zagrebačkog javnog prijevoza. Diplomski rad. Zagreb: Edward Bernays University College.

- Jugo, D. (2012). Strategije odnosa s javnošću. Zagreb: Profil Knjiga, Novelti Milenium.

- Kotler, P. (1994). Upravljanje marketingom. Zagreb: Informator.

- Lennardt, S. (2009). Strategische Kommunikation in regulierten Märkten. Dortmund: LIT.

- Matković, M. (2016). Distribucija audio i vizualnih djela elektroničkim medijima (intervju). Zagreb.

- Milas, Z. (2011). Uvod u korporativnu komunikaciju, Teorijski pristupi i organizacijski modeli. Zagreb: Novelti Milenium.

- Osredečki, E. (1995). Odnosi s javnošću. Samobor/Zagreb: Naklada Edo.

- Skoko, B. (2004). Kvantitativni i kvalitativni dosezi odnosa s javnošću u Hrvatskoj 2003. Medijska istraživanja, 1 (1), $67-82$.

- Skoko, B. (2006). Priručnik za razumijevanje odnosa s javnošću. Zagreb: MPR.

- Šobota, V. (2011). 120 godina ZET-a. Zagreb: Zagrebački holding d.o.o. - podružnica ZET.

- Tomašević, A. (2002). Razvoj teorije i prakse odnosa s javnošću, Marketing u praksi, 9, 6-10.

- Tomić, Z. (2008). Odnosi s javnošću teorija i praksa. Zagreb/Sarajevo: Synopsis.

- Tkalac Verčić, A. (2016). Odnosi s javnošću. Zagreb: HUOJ.

- Oeckl, A. (1976). PR-Praxis. Der Schlüssel zur Öffentlichkeitsarbeit. Düsseldorf/Wien: Econ.

- Ronneberger, F., Rühl, M. (1992). Theorie der Public Relations. Ein Entwurf. Opladen: Westdeutscher Verlag.

- Zakon o izmjeni Zakona o Vladi Republike Hrvatske (1992). Narodne novine, 88/92, Zagreb.

\section{Internetski izvori}

- 24sata (21.6.2007). Bahate ZET-ovce odsad prijavite na besplatan broj. Preuzeto s http://www.24sata.hr/news/bahate-zetovce-odsad-prijavite-na-besplatan-broj-21423, 25.10.2016.

- Godišnje izvješće 2015. (2016). Zagrebački holding d.o.o. Preuzeto s http://www.zgh.hr/UserDocsImages/dokumenti/izvjesca/ Godišnje\%20izvješće_2015_ZGH\%20d.o.o..pdf, 6.11.2016. 
- HUOJ (2016). Hrvatska udruga za odnose s javnošću. Preuzeto s http://www.huoj.hr/index.php?opt=news \&act=mlist\&id= 401\&lang=hr, 5.10.2016.

- IKA (2011). Interni informativni program tijekom posjeta Pape u ZET-ovim vozilima. Informativna katolička agencija, 1. lipnja 2011., Preuzeto s: http://www.ika.hr/index.php?prikaz=vijest \&ID=132423, 26.11.2016.

- Tportal (2014). Nakon nevremena ZET otvorio besplatni telefon, 30. srpnja 2014. Preuzeto s: http://www.tportal.hr/vijesti/ hrvatska/344908/Nakon-nevremena-ZET-otvorio-besplatni-telefon.html, 25.11.2016

- Šobak, M. (2016). Mislili smo pokuditi, ali Holdingov pozivni centar jednostavno moramo pohvaliti. Večernji.hr, 3. veljače 2016. Preuzeto s http://www.vecernji.hr/zg-zivot/mislili-smo-pokuditi-ali-holdingov-pozivni-centar-jednostavno-moramopohvaliti-1057187, 22.11.2016.

- Večernji list (2011). Radio ZET počeo emitirati u svim tramvajima. Večernji.hr, 18. lipnja 2011. Preuzeto s http://www.vecernji. $\mathrm{hr} /$ zg-vijesti/radio-zet-poceo-redovno-emitirati-u-svim-tramvajima-301909, 24.11.2016.

- Zagreb (2009). Kontakt centar ZET-a. Zagreb.hr, 25. listopada 2016. Preuzeto s: http://www.zagreb.hr/default.aspx?id=15513, 25.10.2016.

- Zagrebačka novinska agencija (2014). Zagrebački javni prijevoz uz Google vidljiv u cijelom svijetu, 7. listopada 2014. Preuzeto s: http://www.zna.hr/?p=9197, 27.11.2016.

- Zagrebački holding (2016). Zagrebački holding d.o.o. - podružnica ZET. Interna dokumentacija. Arhiv ZET-a.

\section{Ostali izvori}

- Narodne novine (1888). Broj 232. 9. listopada 1888., Zagreb.

- Narodne novine (1888). Broj 293. 21. prosinca 1888., Zagreb.

- Dom i sviet (1888). Broj 21. 1. studenoga 1888., Zagreb.

- Obzor (1889). 16. svibnja 1889. Zagreb (mikrofilm, Arhiv NSK).

- GPP (1885)

- Vjesnik (2007) 


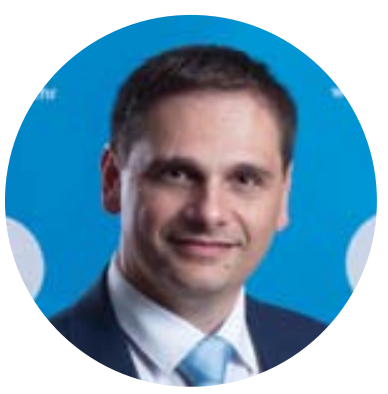

\section{Zdeslav Milas}

Zdeslav Milas was born in Zagreb. From 1975 to 1991, he lived and grew up in Vienna, where he graduated from a Catholic high school. He obtained a degree in journalism and his master's from the Faculty of Philosophy in Mostar. He is a $\mathrm{PhD}$ candidate of Josip Juraj Strossmayer University of Osijek. Since 2013, he has been the Vice Dean of Education and Head of the Public Relations Department at Edward Bernays University College. Milas is involved in teaching as a senior lecturer in the group of subjects in the field of public relations.

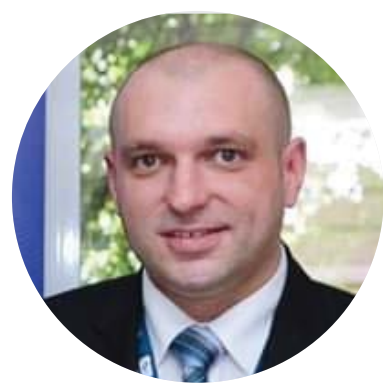

\section{Tomislav Jurić}

Tomislav Jurić, PR specialist, was born in Zagreb. During the period from 1997 to 2006 he worked in journalism, mostly in Radio Sljeme broadcasting program of Croatian Radio and Television. He has been working intensively in the profession of public relations since 2007, when he was employed as a first spokesperson in Zagreb Electric Tram where he integrates contemporary communication practice. Today he is the director of the Joint Affairs Service of Zagreb Holding, where he is mostly engaged in the field of customer and investor relations. 